(eds) Root and Butt Rots of Forest Trees (10 ${ }^{\text {th }}$ International Conference on Root and Butt Rots). Proceedings of the IUFRO Working Party 7.02.01, Quebec City, Canada, Sept 16-22, 2001. Information Report LAU-X126, Canadian Forest Service: 160-169.

VASILIAUsKas, R. and J. STEnlid (1998): Spread of S and P group isolates of Heterobasidion annosum within and among Picea abies trees in central Lithuania. Canadian Journal of Forest Research 28: 961-966.

WAGN, O. (1987): Smitteforsøg med rodfordærveren, Fomes annosus (Fr.) Cooke, i lætræer. II Afsluttende opgørelse. [Infection experiment with annosus root rot, Fomes annosus (Fr.) Cooke in shelter trees. II Final report.] Tidsskrift for Planteavl 91(2), 173-181.

Werner, A. and P. LAKomy (2003): Pathogenecity of P-, S-, and F-intersterility groups of Heterobasidion annosum to Scots pine, Norway spruce and common fir in inocu- lation experiments. In: LAFlamme, G., BÉRUBÉ, J. A., Bussières, G. (eds) Root and Butt Rots of Forest Trees (10 ${ }^{\text {th }}$ International Conference on Root and Butt Rots). Proceedings of the IUFRO Working Party 7.02.01, Quebec City, Canada, Sept 16-22, 2001. Information Report LAU-X-126, Canadian Forest Service: 310-317.

Woodward, S., J. STEnlid, R. KarJalainen and A. HÜtTERMAN (eds). (1998): Heterobasidion annosum: Biology, Ecology, Impact and Control. CAB International. 589 pp.

YDE-ANDERSEN, A. (1962): Seasonal Incidence of Stump Infection In Norway Spruce by Air-Borne Fomes annosus Spores. Forest Science 8(2): 98-103.

YDE-ANDERSEN, A. (1971): Rodfordærverangreb i forbindelse med skærmstilling og underplantning af bjergfyrbevoksninger. - Det Forstlige Forsøgsvæsen i Danmark 32: 379-398.

\title{
Microsatellites Reveal Clonal Growth and Genetically Distinct Groups in Cryptocarya chinensis in Fragmented Lower Subtropical Forest, China
}

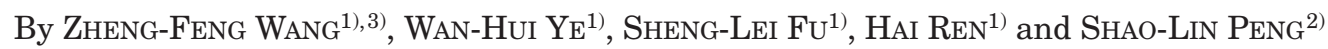

(Received 14 ${ }^{\text {th }}$ August 2007)

\begin{abstract}
The lower subtropical monsoon evergreen broadleaved forest in South China (about $22^{\circ} \sim 24^{\circ} \mathrm{N}$ ) has a high conservation status, because of its uniqueness and high biodiversity. During the last few decades, most of these forests have been destroyed, and the remaining are being degraded by fragmentation. However, genetic information concerning the effects of fragmentation is currently lacking for plant species in these forests. In this study, therefore, eight microsatellites were used to study six Cryptocaya chinensis fragmented populations in Guangdong Province South China, and the results revealed a complex pattern of genetic variation within and among $C$. chinensis populations. Firstly, genetic variations demonstrate hitherto undetected clonal growth in $C$. chinensis. Secondly, current population structure of $C$. chinensis reflects an interaction between ancient homogeneous level of genetic variation and con-

\footnotetext{
1) Zheng-Feng Wang, Wan-Hui Ye, Sheng-Lei Fu, Hai Ren. Guangdong Key Laboratory of Digital Botanical Garden, South China Botanical Garden, Chinese Academy of Sciences, Guangzhou 510650, P. R. China.

2) Shao-Lin Peng. School of Life Sciences, Sun Yat-sen University, Guangzhou 510275, P. R. China.

3) Correspondence: Zheng-Feng WANG. South China Botanical Garden, Chinese Academy of Sciences, XingKe Route 723, TianHe, Guangzhou 510650, P. R. China. Tel: +86-20-
} 37252996, Fax: +86-20-37252615, E-mail: wzf@scib.ac.cn
\end{abstract}

temporary bottleneck via fragmentation. Small populations maintain substantial genetic variation of the initial populations through clonal growth, and do not show genetic depauperation compared to larger populations. Finally, two genetically distinct groups (West and Middle-East groups) are found in this area, connected by highly mixed contact zone.

Key words: clonal growth, Cryptocarya chinensis, habitat fragmentation, microsatellite, genetically distinct groups, contact zone, genetic diversity.

\section{Introduction}

The fragmentation of continuous habitat into smaller patches is a world-wide phenomenon. Its effects have been discussed and studied comprehensively (HoBBs and YATES, 2003; Honnay et al., 2005; REED, 2004). Fragmentation leads to restricted gene flow among populations, leading to loss of alleles, increased inbreeding and genetic drift within populations (HAMRICK and GODT, 1996; Young et al., 1996), and eventually influence species long-term persistence (FRANKHAM, 2005). Sometimes, however, fragmented populations may experience normal or even enhanced gene flow and do not suffer from genetic erosion (Young et al., 1996, references therein, WHITE et al., 2002). Clonal growth is another way that may mitigate the adverse effect of habitat frag- 
mentation by retarding the loss of genetic variability (HonNAY and BossuYT, 2005; HonNAY et al., 2005).

Lower subtropical monsoon evergreen broad-leaved forests are found in the tropical-subtropical transition zone in southern China (about $22^{\circ} \sim 24^{\circ} \mathrm{N}$ ), near the Tropic of Cancer. In contrast to similar latitudinal areas elsewhere, which are almost all dry or semidry lands, unique and luxuriant subtropical forests are well developed in southern China because of their proximity to the Pacific Ocean to the east and the Indian Ocean to the south, which bring abundant rain in spring and summer (DiNG et al., 2001).

Guangdong Province is the main distribution area of lower subtropical monsoon evergreen broad-leaved forests. Historically, however, there has been severe deforestation in Guangdong Province (GDSQZB, 1991). Instability of the society (like World War II and the following civil war) caused heavy deforestation in the Guangdong Province in the early 1900s (FORESTS OF GUANGDONG, 1990). By 1949, the forest cover in Guangdong Province was only $17.6 \%$. It restored to $27.7 \%$ in 1985 gradually, and increased rapidly to $56.6 \%$ in 1998 but mainly due to man-made forest plantations. However, even during these years of forest expansion (1949-1998), in 1958, 1968 and 1978, there were three large-scale deforestations (cutting for woods) of natural forests in Guangdong Province (ZHOU and CHOKKALINGAM, 2004). At present, the natural forest cover is only $1.5 \%$ (XuE et al., 2005). Current overexploitation and the environmental deterioration that is accompanying economic development in this area have made the problem of destruction even worse. Today, lower subtropical monsoon evergreen broad-leaved forests have been reduced to a few isolated patches, which are currently protected because of their key role in the lower subtropical ecosystem (MA, 1999).

As a successional climax species, Cryptocarya chinensis (Hance) Hemsl. (Lauranceae) is the main component of typical monsoon evergreen broad-leaved forest in lower subtropical China (PENG, 1996; SUN, 1998; ZHENG, 2002). C. chinensis is a forest-dwelling species and occupies the second or third level of the tree layer. As a result of the destruction of the monsoon evergreen broad-leaved forest, it is now patchily distributed and an ideal system to study the influence of forest fragmentation on the population genetics of forest species. In fact, common species, alike to rare and endemic species, could also greatly suffer from habitat fragmentation (Hooftman et al., 2003; JUMP and PEÑUELAs, 2006).

Therefore, the main aim of the present study is to examine levels of genetic variation within and among six $C$. chinensis fragmented populations in lower subtropical China in order to determine whether any genetic effects of habitat fragmentation are detectable. Given the severe deforestation in this area, we might expect to detect evidence of severe bottlenecking within populations, as well as genetic differentiation among populations due to restricted gene flow resulting from forest fragmentation. In addition, we also report the genetic characteristic of clonal growth in $C$. chinensis. That is, strong negative $F_{I S}$, high occurrence of identical genotypes and nearly complete and significant multilocus linkage disequilibrium for clonal species (BALLOUX et al., 2003; De Meeûs and Balloux, 2004; Halkett et al., 2005).

\section{Materials and Methods}

\section{Study species}

To date, the biology and ecology of C. chinensis is poorly characterised. $C$. chinensis is a common evergreen tree, widely distributed in southern China, growing up to 20 meters high. It can live for 50 years and more (LIU $\mathrm{S}-\mathrm{Z}$, personal communication). C. chinensis is a halfshade tolerant species: high dense canopy will prevent its regeneration. Hermaphroditic flowers form paniculate inflorescences and are pollinated by insects. Seeds of $C$. chinensis are dispersed by vertebrates (e.g. birds and small mammals) and gravity (WANG et al., 2003).

\section{Samples collection}

Six fragmented populations were selected for leaf sample collection between 2003 and 2004 from the lower subtropic, Guangdong Province, China (Fig. 1, Table 1). HSD, DWL, DHS, GT are natural reserves where C. chinensis is currently relatively well preserved. RP and GT are small patches near villages, newly cutting of C. chinensis are seen throughout these two sampling areas, indicationg intensive human disturbance. There are only five and four large trees remaining in LG and RP populations, respectively. These six C. chinensis populations are considered to occur via natural regeneration rather than through human mediated planting.

Leaf samples were randomly collected with each at least $30 \mathrm{~m}$ apart and to cover the whole area in populations. Because LG and RP are small patches with area small than 1 ha, for these two populations, samples were collected without considering the distance between them.

Leaf samples were placed in sealed plastic bags containing silica gel until DNA extraction. Eight microsatellite loci (GenBank accession number: DQ679889DQ679896) were analysed using the amplification procedures previously published by WANG et al. (2007). Individuals with missing data due to amplification failure were excluded for subsequent "genet-level" analyses.

\section{Data analysis}

All data format convertions were aided with software CONVERT 1.3 (GLAUBITZ, 2004).

\section{Clonal growth}

Wright's $F$-statistics $\left(F_{I S}, F_{I T}\right.$ and $F_{S T}$ ) (WEIR and CoCKERHAM, 1984) (with and without multiloci genotype repeats) were calculated and tested for significance using SPAGeDi 1.2e (HARDY and VEKEMANS, 2002). Linkage disequilibrium was estimated using the correlation coefficient $\left(R_{G G D}\right)$ and multilocus linkage disequilibrium $\left(r_{D}\right)$ as DE MEEÛs and BALloux (2004) suggested. $R_{G G D}$ was calculated using LINKDOS program incorporated in GENEPOP 3.3 (RAYMOND and RoUSSET, 1995), $r_{D}$ was calculated with MULTILOCUS 1.3b (AGAPOW and BURT, 2001). Genotypic diversity (the occurrence of identical genotypes) was estimated with $G / N$, where $G$ was num- 


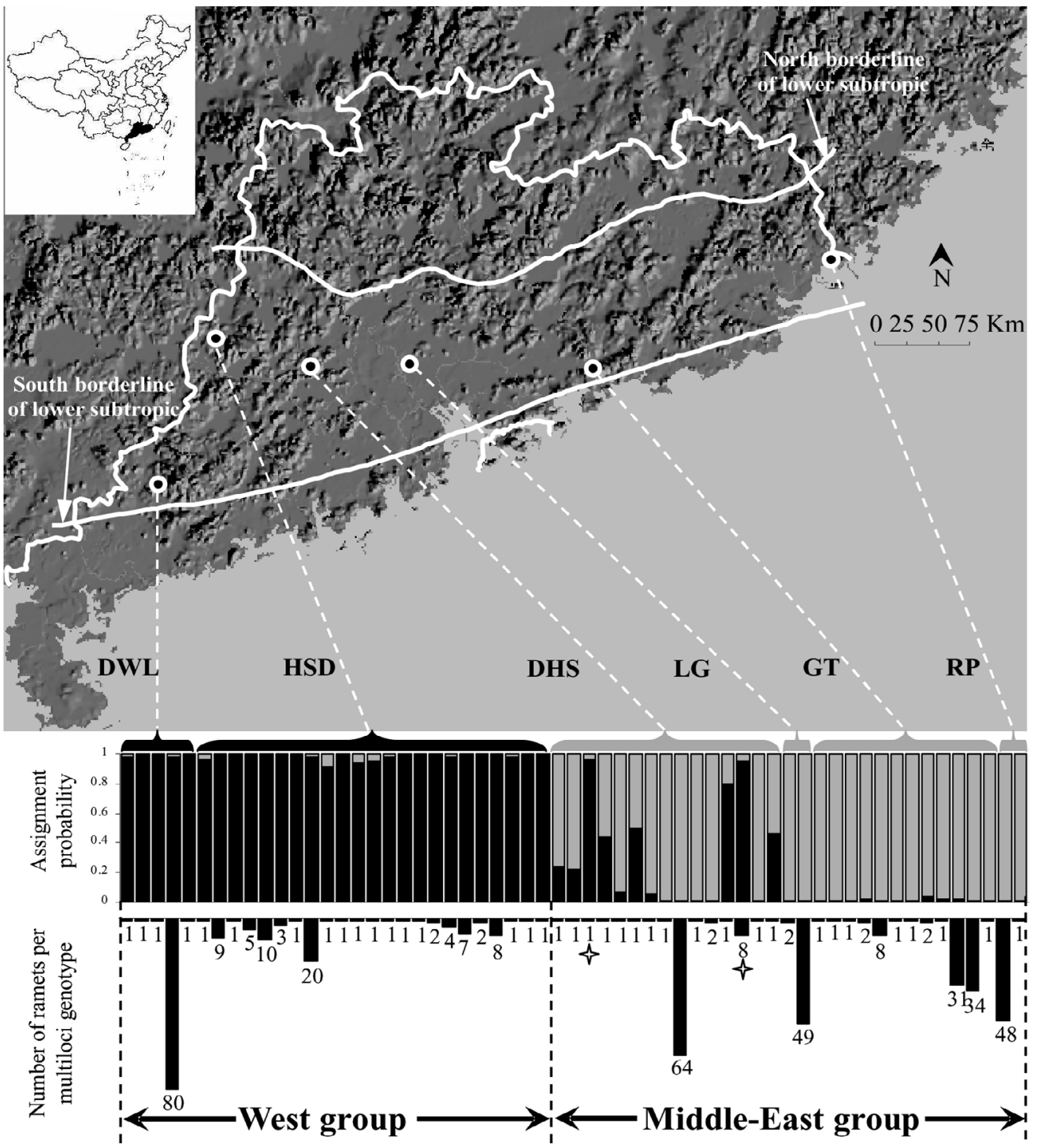

Figure 1. - Sampling location of six Cryptocarya chinensis populations in Guangdong Province China, combining with the results of STRUCTURE analysis using 59 multilocus genotypes. Lower subtropical boundaries are according to GDSQZB (1991) and abbreviations of sites are as described in Table 1. STRUCTURE analysis recovers two groups $(K=2$, West and Middle-East groups). The bars directly below sampling maps represent the assignment probability that each multilocus genotype belongs to a particular group (illustrated by black and grey colours). The bar under each "assignment probability" bar indicates the number of ramets for each multiloci genotype. Two "mis-assigned" multilocus genotype to West group in DHS population are indicated by starts.

ber of observed multilocus genotypes, $N$ was number of sample size.

\section{Genetic variation and structure}

In order to provide a full and unbiased characterization of the genetic variation and clonal structure of a species the data should be analysed using all ramets (with multiloci genotype repeats) as well as all genets (without multiloci genotype repeats) (DE MEeÛs et al., 2006; IVEY and RICHARDS, 2001; SUZUKI et al., 2004). Therefore, we used both data sets to conduct the subsequent analyses. If the calculation with and without multiloci genotype repeats gave similar results we only reported the latter unless otherwise stated. Within the text, genetic diversity parameters subscriped with an "s" indicate species values, while those subscriped with a " $p$ " indicated population means.

\section{Genetic diversity}

Genetic diversity was described by observed heterozygosity $\left(H_{0}\right)$, the unbiased expected heterozygosity $\left(H_{e}\right.$, NEI, 1978). $H_{0}$ and $H_{e}$ were calculated using GDA 1.1 (LEWIS and ZAYKIN, 2001).

\section{Genetic differentiation}

Pairwise $F_{S T}$ values between populations using data set with multiloci genotype repeats were calculated according to WEIR and COCKERHAM (1984) and tested for significance using SPAGeDi 1.2e (HARDY and VEKEMANS, 2002). 
Table 1. - Description of populations studied for Cryptocarya chinensis including locations and their descriptions, population sizes, altitude we collected samples, sample sizes $(N)$, number of multiloci genotypes $(G)$, genotypic diversity $(G / N)$.

\begin{tabular}{|c|c|c|c|c|c|c|c|c|c|}
\hline Population & Name & $\begin{array}{l}\text { Latitude and } \\
\text { longitude }\end{array}$ & $\begin{array}{l}\text { Site description } \\
\text { (established year) }\end{array}$ & Area (ha) & Population size & Altitude (m) & $N^{a}$ & $G^{\mathrm{b}}$ & $G / N^{c}$ \\
\hline HeiShiDing & HSD & $23^{\circ} 27^{\prime} \mathrm{N}, 111^{\circ} 53^{\prime} \mathrm{E}$ & $\begin{array}{c}\text { Guangdong Natural } \\
\text { Reserve (1979) }\end{array}$ & 4200 & $>5000$ & $300 \sim 600$ & 86 & 23 & 0.277 \\
\hline DaWuLing & DWL & $22^{\circ} 15^{\prime} \mathrm{N}, 111^{\circ} 10^{\prime} \mathrm{E}$ & $\begin{array}{c}\text { Guangdong Natural } \\
\text { Reserve (1996) }\end{array}$ & 3534 & $>2000$ & $600 \sim 800$ & 88 & 5 & 0.060 \\
\hline DingHuShan & DHS & $23^{\circ} 08^{\prime} \mathrm{N}, 112^{\circ} 35^{\prime} \mathrm{E}$ & $\begin{array}{l}\text { National Natural } \\
\text { Reserve (1956) }\end{array}$ & 1133 & $\begin{array}{l}0.13 \text { individuals } / \mathrm{m}^{2} \\
\text { (W } \mathrm{N} \mathrm{NG} \text { et al. } 2003 \text { ) }\end{array}$ & $100 \sim 400$ & 89 & 15 & 0.174 \\
\hline LuoGang & LG & $23^{\circ} 08^{\prime} \mathrm{N}, 113^{\circ} 19^{\prime} \mathrm{E}$ & $\begin{array}{l}\text { Small patch near } \\
\text { village }\end{array}$ & $<1$ & $\approx 300$ (WANG et al. 2005 ) & 50 & 49 & 2 & 0.041 \\
\hline GuTian & GT & $23^{\circ} 06^{\prime} \mathrm{N}, 114^{\circ} 47^{\prime} \mathrm{E}$ & $\begin{array}{c}\text { Guangdong Natural } \\
\text { Reserve (1984) }\end{array}$ & 2189 & $>5000$ & $300 \sim 500$ & 87 & 12 & 0.143 \\
\hline \multirow[t]{2}{*}{ RaoPing } & $\mathrm{RP}$ & $23^{\circ} 49^{\prime} \mathrm{N}, 117^{\circ} 00^{\prime} \mathrm{E}$ & $\begin{array}{l}\text { Small patch near } \\
\text { village }\end{array}$ & $<1$ & $\begin{array}{c}<200 \text { (WZF, personal } \\
\text { observation) }\end{array}$ & 100 & 49 & 2 & 0.041 \\
\hline & & & & & & & & Total & 0.136 \\
\hline
\end{tabular}

a We do not differ "ramet" and "genet" in field.

b Individuals with missing data are excluded.

c Individuals with missing data are excluded.

\section{Bottleneck test}

Wilcoxon test for heterozygote excess under Infinite Allele Model (IAM) were performed to exam population bottleneck using BOTTLENECK 1.2.02 (CORNUET and LUIKART, 1996; LUIKART et al., 1998). Interrupted or compound microsatellites in our analysis (WANG et al., 2007) were likely to fit the IAM better (CORNUET and LUIKART, 1996).

\section{Substructure test}

To test if the six populations represented genetically distinct groups $(K)$, a Bayesian cluster analysis was performed using the program STRUCTURE 2.1 (FALUSH et al., 2003; PRITCHARD et al., 2000). Using a model assuming admixture of source populations and correlated allele frequencies between groups, twenty independent runs were performed for each $K$ (from 1 to 6 ) for $10^{6}$ iterations after a burn-in period of $10^{6}$ on total multiloci genotypes without prior concerning of their origin populations. The choice of the appropriate $K$ value was conducted as recommended in STRUCTURE user's manual. Preferred $K$ was also examined by $\Delta K$ (EvANNo et al., 2005). In most case, the maximal value of $\Delta K$ might indicate the correct estimation of $K$.

\section{Results}

\section{Clonal growth}

Estimates of $F_{I S}$ indicated a general excess of heterozygotes, seven of eight loci showed highly significant negative of $F_{I S}$ (Table 2). There was a significant excess of heterozygotes with a mean $F_{I S}$ over all loci of -0.596 .

Table 2. - Summary of $F$-statistics at eight microsatellite loci with and without multiloci genotype repeats for Cryptocarya chinensis.

\begin{tabular}{|c|c|c|c|c|c|c|}
\hline \multirow{2}{*}{ Loci } & \multicolumn{3}{|c|}{ With multiloci genotype repeats } & \multicolumn{3}{|c|}{ Without multiloci genotype repeats } \\
\hline & $F_{I T}$ & $F_{I S}$ & $F_{S T}$ & $F_{I T}$ & $F_{I S}$ & $F_{S T}$ \\
\hline Cch01 & $-0.191 * *$ & $-0.626^{* * *}$ & $0.268^{* * *}$ & -0.055 & $-0.239^{* * *}$ & $0.148^{* * *}$ \\
\hline $\mathrm{Cch} 02$ & $-0.214 * *$ & $-0.763 * *$ & $0.311^{* *}$ & $-0.184^{* *}$ & $-0.364^{* *}$ & $0.132 \% *$ \\
\hline $\operatorname{Cch} 03$ & $0.524 * *$ & $-0.190 * *$ & $0.600 * *$ & $0.420^{* *}$ & $0.257^{*}$ & $0.220 \% *$ \\
\hline $\mathrm{Cch04}$ & -0.054 & $-0.579 * *$ & $0.333^{* * *}$ & -0.096 & $-0.250^{*}$ & $0.124^{* *}$ \\
\hline Cch05 & $-0.257 * *$ & $-0.754^{* *}$ & $0.283^{* *}$ & $-0.159^{*}$ & $-0.413 * *$ & $0.180 * *$ \\
\hline Cch06 & $0.913^{* *}$ & $0.743^{* * *}$ & $0.660^{* *}$ & $0.753 * *$ & $0.653^{* *}$ & $0.289 * *$ \\
\hline $\operatorname{Cch} 07$ & $-0.178 * *$ & $-0.687^{* *}$ & $0.302 * *$ & -0.087 & $-0.252^{* *}$ & $0.132^{* *}$ \\
\hline $\operatorname{Cch} 08$ & $-0.531 * *$ & $-0.902 * *$ & $0.195 * *$ & $-0.480^{* *}$ & $-0.772 * *$ & $0.165^{* * *}$ \\
\hline $\begin{array}{c}\text { Overall } \\
\text { loci }\end{array}$ & -0.016 & $-0.596 * *$ & $0.364^{* * *}$ & 0.006 & $-0.201 * *$ & $0.172^{\text {*k }}$ \\
\hline
\end{tabular}

$* P<0.05, * * P<0.01$ (after 5000 permutations). 
$76 \%$ of the pairwise correlation coefficient $\left(R_{G G D}\right)$ were significantly greater than zero after Bonferroni correction $(\alpha<0.05), 91 \%$ of the multilocous linkage disequilibrium values $\left(r_{D}\right)$ between loci were positive (most of them greater than 0.5) and significant after Bonferroni correction $(\alpha<0.05)$, indicating high $\mathrm{LD}$ between the loci.

Among 448 individuals that were genotyped, a total of 59 different multiloci genotypes could be identified, and no population shared the same multiloci genotypes (Fig. 1). There were only two multiloci genotypes for the LG and RP populations, and one or two multiloci genotypes dominated the other four populations. Overall genotypic diversity $(G / N)$ was 0.136 .

\section{Genetic variation and structure}

Genetic diversity

All estimates of genetic diversity for HSD population were highest compared to other populations. Two small populations, LG and RP, did not show decreased genetic diversity. RP population displayed lowest genetic diver- sity in $H_{E}$ with multiloci genotype repeats. On the contrary, LG population showed moderate genetic diversity in general (Table 3).

\section{Genetic differentiation}

Significantly higher genetic differentiation was found between West and Middle-East populations compared to the differentiation within West or Middle-East populations (Table 4).

\section{Bottleneck test}

Wilcoxon test for population bottleneck revealed significant bottleneck in all tested populations $(P<0.05)$ under IAM (Table 3).

\section{Substructure test}

Mean Log-likelihood increased greatly from $K=1$ to $K=2$, and began to plateau until $K=4$ (Fig. 2). According to Pritchard and Wen (2004)'s "more-or-less plateaus" statement, $K=2$ was then most probable. $\Delta K$ was highest at $K=2$, confirming that two groups was

Table 3. - Observed heterozygosity $\left(H_{O}\right)$, Expected heterozygosity $\left(H_{E}\right)$ and BOTTLENECK test for Cryptocarya chinensis, and comparing with other Cryptocarya species and species having similar life-history traits. Numbers in grey shading indicate the highest, boxed the lowest of $H_{O}$ or $H_{E}$ in populations. LG and RP populations were excluded from $H_{O}$ and $H_{E}$ calculation and BOTTLENECK test due to their multiloci genotypes as low as two. Abbreviations of sites are as described in Table 1.

\begin{tabular}{|c|c|c|c|c|}
\hline Population & $H_{O}$ & $H_{E}$ & $F_{S T}$ & 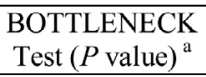 \\
\hline \multicolumn{5}{|c|}{ Data with multiloci genotype repeats } \\
\hline HSD & 0.800 & 0.582 & \multirow{8}{*}{0.364} & 0.0039 \\
\hline DWL & 0.747 & 0.388 & & 0.0117 \\
\hline DHS & 0.649 & 0.455 & & 0.0273 \\
\hline LG & 0.745 & 0.399 & & 0.0078 \\
\hline GT & 0.715 & 0.499 & & 0.0039 \\
\hline RP & 0.750 & 0.380 & & 0.0078 \\
\hline \multirow[t]{2}{*}{ Overall } & $0.732\left(H_{o s}\right)$ & $0.675\left(H_{e s}\right)$ & & \\
\hline & $0.734\left(H_{o p}\right)$ & $0.450\left(H_{e p}\right)$ & & \\
\hline \multicolumn{5}{|c|}{ Data without multiloci genotype repeats } \\
\hline HSD & 0.777 & 0.626 & \multirow{8}{*}{0.172} & 0.00195 \\
\hline DWL & 0.700 & 0.508 & & 0.00781 \\
\hline DHS & 0.658 & 0.608 & & 0.00977 \\
\hline LG & - & - & & - \\
\hline GT & 0.667 & 0.584 & & 0.00195 \\
\hline $\mathrm{RP}$ & - & - & & - \\
\hline Overall & $0.714\left(H_{o S}\right)$ & $0.687\left(H_{e s}\right)$ & & \\
\hline & $0.707\left(H_{o p}\right)$ & $0.582\left(H_{e p}\right)$ & & \\
\hline $\begin{array}{c}\text { Cryptocarya } \\
\text { aschersoniana }^{\mathrm{b}}\end{array}$ & $0.324\left(H_{o p}\right)$ & $0.365\left(H_{e p}\right)$ & $0.320\left(G_{S T}\right)^{\mathrm{c}}$ & \\
\hline $\begin{array}{c}\text { Cryptocarya } \\
\text { moschata }\end{array}$ & $0.344\left(H_{o s}\right)$ & $0.531\left(H_{e s}\right)$ & 0.285 & \\
\hline \multicolumn{5}{|c|}{ Data from $\mathrm{SSR}^{\mathrm{e}}$} \\
\hline \multirow{4}{*}{$\begin{array}{c}\text { Long-lived } \\
\text { perennial } \\
\text { Regional } \\
\text { mixed mating } \\
\text { Late successional } \\
\text { status } \\
\end{array}$} & 0.63 & 0.68 & 0.19 & \\
\hline & 0.65 & 0.65 & 0.28 & \\
\hline & 0.51 & 0.60 & 0.26 & \\
\hline & 0.66 & 0.70 & 0.17 & \\
\hline
\end{tabular}

a after 10000 permutations.

b Moraes and Derbyshire (2003).

c $G_{S T}$, analogy to $F_{S T}$.

d Moraes and Derbyshire (2004).

e Genetic diversity $\left(H_{O}\right.$ and $\left.H_{E}\right)$ were population means (NyBOM, 2004).

$\mathrm{f}$ Mixed mating system indicated by other Cryptocaya species (MORAES and DeRBYSHIRE, 2002). 
Table 4. - Pairwise $F_{S T}$ for six Cryptocarya chinensis populations. Populations are ordered in the table according to the groups (West and Middle-East groups) they belong to. Abbreviations of sites are as described in Table 1 .

\begin{tabular}{|c|c|c|c|c|c|c|c|}
\hline & & \multicolumn{2}{|c|}{ West group population } & \multicolumn{4}{|c|}{ Middle-East group population } \\
\hline & & HSD & DWL & DHS & LG & GT & $\mathrm{RP}$ \\
\hline \multirow{2}{*}{$\begin{array}{l}\text { West group } \\
\text { population }\end{array}$} & HSD & - & & & & & \\
\hline & DWL & $0.2572 * *$ & - & & & & \\
\hline \multirow{4}{*}{$\begin{array}{l}\text { Middle-East } \\
\text { group } \\
\text { population }\end{array}$} & DHS & $0.3493 * *$ & $0.4798 * *$ & 一 & & & \\
\hline & LG & $0.4097 * *$ & $0.5228^{* *}$ & $0.3337^{* *}$ & - & & \\
\hline & GT & $0.2791 * *$ & $0.4215^{* *}$ & $0.2103^{* *}$ & $0.3137 * *$ & - & \\
\hline & $R P$ & $0.4150^{* *}$ & $0.4939 * *$ & $0.3219 * *$ & $0.3824^{* *}$ & $0.2144 * *$ & - \\
\hline
\end{tabular}

** $P<0.01$ (after 5000 permutations).

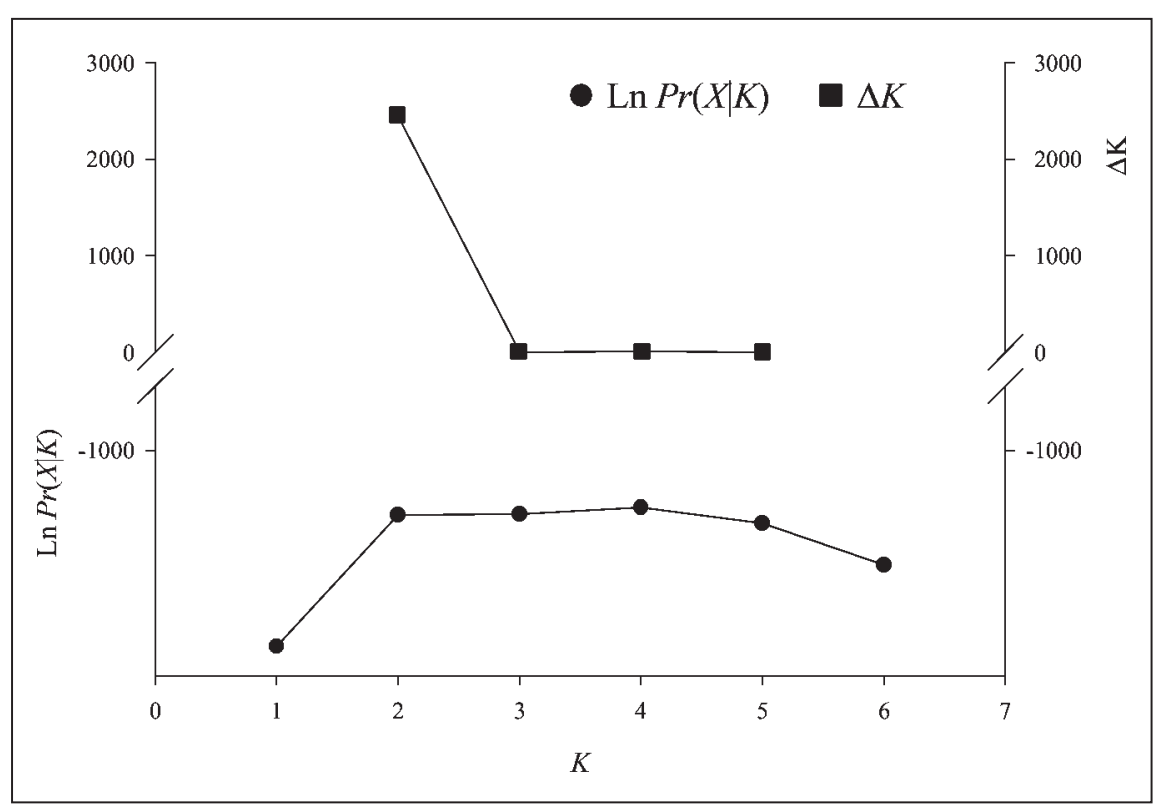

Figure 2. - Magnitude of $\operatorname{Ln} \operatorname{Pr}(X \mid K)$ and $\Delta K$ to infer the genetic groups $(K)$ in STRUCTURE analysis. Ln $\operatorname{Pr}(X \mid K)$ refers to the mean log likelihood estimate using 20 independent runs for each $K$ value. $\Delta K$ is calculated according to EvanNo et al. (2005).

the correct estimation (Fig. 2). Two groups also had a clear geographical correspondence, as one group contained HSD and DWL populations (West group) and the other group contained DHS, LG, GT and RP (MiddleEast group).

Twenty STRUCTURE runs at $K=2$ produced nearly identical individual assignment probability, we just chose the one with the highest log likelihood at $K=2$ to graph the individual assignment probability (Fig. 1). In DHS population, two individuals (indicated with stars in Fig. 1) had a relatively high probability (assignment probability $>0.95$ ) to be migrants or offspring of migrants from the West group, and some individuals showed a fairly high degree of admixture. For the other five populations, however, almost all individuals showed that they were likely to descend from one of "pure" West or Middle-East ancestry.

\section{Discussion}

\section{Unexpected clonal growth}

Strong negative $F_{I S}$ estimates (meaning excess of heterozygote, Table 2), high occurrence of identical genotypes $(G / N$ values, Table 1$)$ and nearly complete and significant multilocus linkage disequilibrium suggest that current growth mode of Cryptocarya chinensis is predominantly clonal (BALlOUX et al., 2003; DE MEEÛS and Balloux, 2004; HalkEtT et al., 2005). Our data also fit very well with DE MEê̂s and BALLOux (2005) strictly clonal species criterion, that was $F_{I T}=0$ and $F_{S T}=-F_{I S} /\left(1-F_{I S}\right)$. Our $F_{I T}$ is -0.01572 , not significantly different from zero (Table 2). The result of $-F_{I S} /$ $\left(1-F_{I S}\right)$ is 0.3734 , very close to the value of $F_{S T}(0.3635)$.

In addition, when the analysis was based on a single representative of each multiloci genotype, the extensive 
linkage disequilibrium between loci almost disappeared (decreasing to $8 \%$ for $R_{G G D}, 9 \%$ for $r_{D}$ after Bonferroni correction), indicating such LD was also main caused by multicopy of each multiloci genotype (clonal growth).

Our overall $G / N$ value of $C$. chinensis is 0.136 , lower than the previously reported value for clonal species (0.17, 21 studies; $0.27,47$ studies, data from Tsyusko et al., 2005). However, these value were obtained by allozyme markers, which might resolve lower diversity than DNA-based markers (ARNAUD-HAOND et al., 2005), our $G / N$ value should be even lower when using the similar allozyme markers, and confirmed extensive clonal growth in $C$. chinensis.

However, highly clonal growth in $C$. chinensis has not previously been detected, and it was always considered sexual growth as way of regeneration (Peng, 1996; WANG et al., 2003). Moreover, the other Cryptocarya species studies also showed no such phenomenon.

Using allozyme, MorAes and Derbyshire (2002; 2003; 2004) studied two other Cryptocarya species' genetic diversities in Brazil, and did not find an excess of heterozygotes as in C. chinensis. Recently, WELLS et al. (2007) used eight micorsatellites to study 623 seedlings and 99 trees of Cryptocarya mackinnoniana, and found no excess of heterozygote within and linkage disequilibrium between loci.

\section{Genetic variation and structure}

\section{Populations suffer from bottleneck}

Compared to "genet-level" genetic variation, clonality does not influence the overall genetic diversity $\left(H_{O}\right.$ and $H_{E}$ ) greatly, but causes a two fold increase in genetic differentiation (Table 3). When multiloci genotype repeats are removed, the single "genet" can be reckoned to derive from sexual reproduction (SMITH et al., 1993; VAUGHAN et al., 2007; WALSER et al., 2004), and its genetic variation can reflect the sexual reproductive status in species. Thus, by comparing with the other similar lifehistory species, the "genet-level" genetic diversity $\left(H_{E}=0.582\right)$ and differentiation $\left(F_{S T}=0.172\right)$ of $C$. chinensis are comparable to or lower than those in other studies ("data from SSR", Table 3).

However, due to severe deforestation history in this area and significant bottleneck, we may expect to find much higher genetic differentiation at genet level, if not much lower genetic diversity. Genetic diversity estimated with $H_{E}$ was less sensitive to bottleneck (SPENCER et al., 2000), and could be influenced by self-incompatible system etc. In Brazil, Moraes and Derbyshire (2003) found forest fragmentation and bottleneck effects caused high genetic differentiation $\left(G_{S T}=0.32\right)$ among population in Cryptocarya aschersoniana.

One reasonable interpretation is that bottleneck are truly severe, but occurred recently. The fragmented populations still harbor the previous genetic homogeneous variation. Moreover, extensive clonal growth and subsequent long generation time actually help to keep these ancient genetic variations for long time, that is why for small populations (LG and RP) we do not find decreased genetic variation compared to larger populations (Table 3).

\section{Two distinct groups and contact zone}

Two distinct groups are clearly demonstrated by pairwise $F_{S T}$ (Table 4), substructure test (using STRUCTURE, Fig. 1). Such separation cannot be caused by naturally occurring barriers, or local selection, but is more likely to be due to independent establishment events.

Although there are mountain ranges (above 1,000 meter in elevation) to separate West and Middle-East populations, GT and RP populations (belong to MiddleEast group) are also divided by one 1,000-meter-high mountain range (Fig. 1). Therefore, it is hard to say that the ones between West and Middle-East groups serve as barrier to gene flow, but not the other one. In addition, pairwise $F_{S T}$ show that the differentiation between HSD and DWL $\left(F_{S T}=0.2572\right)$ is relatively lower than that between HSD and DHS $\left(F_{S T}=0.3493\right)$ (Table 4), although the geographic distance between the former two is twice as far as the later two.

Local selection can be unlikely. Firstly, our sampled populations are located in the same climate zone. Secondly, at least two mis-assigned DHS multiloci genotypes (Fig. 1) that are believed to represent migration from the other group have been found, one of them even has the second highest number of duplicate ramets of the same multiloci genotype (8 repeats). If local selection happens, the "migration" may not spread its "ramets" so successfully considering our fully random sampling.

Therefore, the formation of two distinct groups in C. chinensis is more likely caused by history independent establishment events. It can also be true, that flora of west lower subtropic is mainly influenced by tropic flora, while the Middle-east flora is mainly influenced by middle subtropic (GDSQZB, 1991). DHS, due to its special geographic location, plays as contact zone to connect the two groups in $C$. chinensis. In addition, according to the results of STRUCTURE, DHS is the only place to find the individuals of admixture because it is geographically close to West group. However, why and when did the westwards or eastwards gene flow cease at the point of DHS? Because of our limited studied populations, we cannot answer this question at present study, and we could also miss some important populations (such as including other relevant westwards or eastwards gene flow) which can provide more information to resolve this problem.

\section{Conclusion}

Historical deforestation in lower subtropic China caused severe bottleneck and highly fragmentation even for common species, like $C$. chinensis, which might also trigger its extensive clonal growth. Although the linkage between fragmentation and clonal growth need further confirmation, the clonal growth actually helps to keep the genetic diversity within and among $C$. chinensis populations. However, even $C$. chinensis is not threatened currently with danger, the consequences of the long term clonal growth may increases the risk of its sexual extinction (HoNNAY et al., 2005; HoNNAY and BossuYT, 2005). Therefore, it is still important to maintain the existing levels of genetic diversity to prevent future genetic risks. The distinguished two groups and contact 
zone clear demonstrate forest fragmentation may restrict the recently eastwards gene flow because Middle-East area of lower subtropic China has remained free of geographic barriers (Fig. 1), though west mountain range could obstacle the westwards gene flow. However, more extensive geographical samplings are required in South China (not just lower subtropic) to make clear the marked separation of West and MiddleEast groups, understanding the exact nature in $C$. chinensis.

\section{Acknowledgement}

We thank San-Hong GaO, Sheng-Ni Tian, Gang LI, Ci-You Zhu, Tian-Min Wu and Wei-Nan Ye for helping collect sampling and/or assistance in the laboratory. We also thank two reviewers to give comments to improve our manuscript. This work was supported by Natural Science Foundation of China (No. 30300055), Natural Science Foundation of Guangdong Province (No. 031264), Science Utility Project of Guangdong Province (No. 2005B60301001) and the International Foundation for Science (No. D/3239-1).

\section{References}

AGAPOW, P.-M. and A. BuRT (2001): Indices of multilocus linkage disequilibrium. Mol Ecol Notes 1: 101-102.

ARnaud-Haond, S., F. Alberto, S. Teixeira, G. ProcacciNI, E. A. Serrão and C. M. Duarte (2005): Assessing genetic diversity in clonal organisms: low diversity or low resolution? Combining power and cost-efficiency in selecting markers. J Here 96: 434-440.

Balloux, F., L. Lehmann and T. De Meeûs (2003): The population genetics of clonal and partially clonal diploids. Genetics 164: 1635-1644.

Cornuet, J. M. and G. Luikart (1996): Description and power analysis of two tests for detecting recent population bottlenecks from allele frequency data. Genetics 144: 2001-2014.

De Meeûs, T. and F. Balloux (2004): Clonal growth and linkage disequilibrium in diploids: a simulation study. Infect Genet Evol 4: 345-351.

De Meeûs, T. and F. Balloux (2005): F-statistics of clonal diploids structured in numerous demes. Mol Ecol 14: 2695-2702.

De Meeûs, T., L. Lehmann and F. Balloux (2006): Molecular epidemiology of clonal diploids: A quick overview and a short DIY (do it yourself) notice. Infect Genet Evol 6: 163-170.

Ding, M.-M., S. Brown and A. E. Lugo (2001): A continental subtropical forest in China compared with an insular subtropical forest in the Caribbean. Gen. Tech. Rep. IITF-17. Río Piedras, PR: Department of Agriculture, Forest Service, Institute of Tropical Forestry. 46p.

Evanno, G., S. Regnaut and J. Goudet (2005): Detecting the number of clusters of individuals using the software STRUCTURE: a simulation study. Mol Ecol 14: 2611-2620.

Falush, D., M. Stephens and J. K. Pritchard (2003): Inference of population structure using multilocus genotype data: linked loci and correlated allele frequencies. Genetics 164: 1567-1587.

FORESTS OF GUANGDONG (1990): edited by Editorial committee for Forests of Guangdong. Guangdong Science and Technology Publishing House and Chinese Forestry Publishing House.
FrankHAM, R. (2005): Genetics and extinction. Biol Conserv 126(2): 131-140.

GDSQZB (1991): Guang Dong Shan Qu Zhi Bei (Vegetation of Guangdong Mountainous Area). Hilly land interdisciplinary study team of Guangdong Academy of Sciences eds. Guangdong Technology Press, Guangzhou, China.

GLAubitz, J. C. (2004): CONVERT: A user-friendly program to reformat diploid genotypic data for commonly used population genetic software packages. Mol Ecol Notes 4: 309-310.

Halkett, F., J.-C. Simon and F. Balloux (2005): Tackling the population genetics of clonal and partially clonal organisms. Trends Ecol Evol 20, 194-201.

HAMRICK, J. L. and M. J. W. GODT (1996): Conservation genetics of endemic plant species, pp. 281-304 in Conservation genetics: Case histories from natures, edited by J. L. AviSE and J. L. HAMrick, Chapman and Hall.

HARDY, O. J. and X. VEKEMANS (2002): SPAGeDi: a versatile computer program to analyse spatial genetic structure at the individual or population levels. Mol Ecol Notes 2: 618-620.

HobBs, R. J. and C. J. YATES (2003): Turner review. No. 7: Impacts of ecosystem fragmentation on plant populations: generalising the idiosyncratic. Aust J Bot 51: 471-488.

Honnay, O. and B. Bossuyt (2005): Prolonged clonal growth: escape route or route to extinction? Oikos 108: 427-432

Honnay, O., H. Jacquemyn, B. Bossuyt and M. Hermy (2005): Forest fragmentation effects on patch occupancy and population viability of herbaceous plant species. New phytol 166: 723-736.

Hooftman, D. A. P., M. Van Kleunen and M. Diemer (2003): Effects of habitat fragmentation on the fitness of two common wetland species, Carex davalliana and Succisa pratensis. Oecologia 134: 350-359.

IvEY, C. T. and J. H. RICHARDS (2001): Genetic diversity of Everglades sawgrass, Cladium jamaicense (Cyperaceae). Int J Plant Sci 162: 817-825.

JUMP, A. S. and J. PEÑUELAS (2006): Genetic effects of chronic habitat fragmentation in a wind-pollinated tree. Proc Natl Acad Sci USA 103: 8096-8100.

Lewis, P. O. and D. ZAYKIN (2001): Genetic Data Analysis: Computer program for the analysis of allelic data. Version 1.0 (d16c). Free program distributed by the authors over the internet from http://lewis.eeb.uconn.edu/ lewishome/software.html.

Luikart, G., F. W. Allendorf, J. M. Cornuet and W. B. SHERWIN (1998): Distortion of allele frequency distributions provides a test for recent population bottlenecks. $\mathrm{J}$ Here 89: 238-247.

MA, K.-P. (1999): Ecosystem Diversity in Key Areas of China. Zhejiang Science and Technology Press, Hangzhou China.

Moraes, P. L. R. and M. T. V. De C. Derbyshire (2002): Estrutura genética de populações naturais de Cryptocarya aschersoniana Mez (Lauraceae)através de marcadores isoenzimáticos. Biota Neotropica, Vol. 2 (número 2): http://www. biotaneotropica.org.br/v2n2/pt/ abstract?article+BN02402022002.

Moraes, P. L. R. and M. T. V. De C. Derbyshire (2003): Diferenciação genética e diversidade em opulaçõesnaturais de Cryptocarya aschersoniana Mez (Lauraceae). Biota Neotropica, v3 (n1) - http://www.biotaneotropica. org.br/v3n1/pt/abstract?article+BN01803012003. 
Moraes, P. L. R. and M. T. V. De C. DerbyshiRe (2004): Genetic structure of natural populations of Cryptocarya moschata Nees (Lauraceae) from southeastern Brazilian Atlantic rain forest. Biota Neotropica, V4 (n 1). http://www.biotaneotropica.org.br/v4n1/pt/abstract? article+BN00404012004

NEI, M. (1978): Estimation of average heterozygosity and genetic distance from a small number of individuals. Genetics 89: 583-590.

Nyвом, H. (2004): Comparison of different nuclear DNA markers for estimating intraspecific genetic diversity in plants. Mol Ecol 13: 1143-1155.

PENG, S.-L. (1996): Southern subtropical forest community dynamics. Science Press China, Beijing, China.

Pritchard, J. K., M. Stephens and P. Donnelly (2000): Inference of population structure using multilocus genotype data. Genetics 155: 945-959.

PRITChARD, J. K. and W. WEN (2004): Documentation for structure software: version2. Chicago. Available at http://pritch.bsd.uchicago.edu/software.html.

RAYMOND, M. and F. ROUSSET (1995): GENEPOP (version 1.2): population genetics software for exact tests and ecumenicism. J Here 86(3): 248-249.

REED, D. H. (2004): Extinction risk in fragmented habitats. Anim Conserv 7: 181-191.

Smith, J. M., N. H. Smith, M. O'Rourke and B. G. Spratt (1993): How clonal are bacteria? Proc Natl Acad Sci USA 90: 4384-4388.

Spencer, C. C., J. E. Neigel and P. L. Leberg (2000): Experimental evaluation of the usefulness of microsatellite DNA for detecting demographic bottlenecks. Mol Ecol 9: 1517-1528.

Sun, S.-Z. (1998): Concerning the vegetation Chinese regionalization map as a part of the natural geographical atlas of the peoples republic of China. Acta Phytoecologica Sinica 22(6): 523-537.

SUZUKI, J.-I., T. HERBEN and M. MAKI (2004): An underappreciated difficulty: sampling of plant populations for analysis using molecular markers. Evol Ecol 18: 625-646.

Tsyusko, O. V., M. H. Smith, R. R. Sharitz and T. C. GLENN (2005): Genetic and clonal diversity of two cattail species, Typha latifolia and T. angustifolia (Typhaceae), from Ukraine. Amer J Bot 92: 1161-1169.

Vaughan, S. P., J. E. Cottrell, D. J. Moodley, T. CoNNOLLY, K. Russell and DR. S. P. VAughaN (2007): Distribution and fine-scale spatial-genetic structure in
British wild cherry (Prunus avium L.). Heredity 98: 274-283.

Walser, J.-C., F. Gugerli, R. Holderegger, D. Kuonen and C. SCHEIDEGGER (2004): Recombination and clonal propagation in different populations of the lichen Lobaria pulmonaria. Heredity 93: 322-329.

WANG, Z.-F., S.-H. GAO, M. J. W. GodT, S.-L. Peng and S. L. FU (2005): Cryptocarya chinensis spatial patterns caused by human disturbance in the lower subtropical monsoon evergreen broad-leaved forest. Acta Ecologica Sinica 25: 3289-3293.

WANG, Z.-F., G. LI, S.-L. FU and H. REN (2007): Isolation and characterization of microsatellite loci in Cryptocarya chinensis in lower subtropical China. Conserv Genet 8: 1235-1237.

Wang, Z.-F., S.-L. PENG, S.-Z. LiU and Z. Li (2003): Spatial pattern of Cryptocarya chinensis life stages in lower subtropical forest, China. Bot Bull Acad Sinica 44: $159-166$

WeIR, B. S. and C. C. Cockerham (1984): Estimating F-statistics for the analysis of population structure. Evolution 38: 1358-1370.

Wells, J. A., M. G. Gardner and A. J. Lowe (2007): Development of eight polymorphic microsatellites for an Australasian rainforest tree species, Cryptocarya mackinnoniana (Lauraceae). Mol Ecol Notes. DOI 10.1111/j. 1471-8286.2007.01745.x

White, G. M., D. H. Boshier and W. Powell (2002): Increased pollen flow counteracts fragmentation in a tropical dry forest: An example from Swietenia humilis Zuccarini. Proc Natl Acad Sci USA 99: 2038-2042.

XUE, C.-Q., J.-Q. LIN, J.-S. YE and M.-S. LI (2005): Ecological situation and constructive countermeasure of forest in Guangdong Province. Guangdong Forestry Science and Technology 21(2): 55-59.

Young A. G., T. BoYle and T. Brown (1996): The population genetic consequences of habitat fragmentation for plants. Trends Ecol Evol 11: 413-419.

ZHENG, S.-Q. (2002): A preliminary research on the vegetation of Jiufu Mountainvin Youxi County, Fujian. Subtropical Plant Science 31(3): 35-40.

ZHoU, Z.-Z. and U. CHOKKALINGAM (2004): Review of forest rehabilitation initiatives in Guangdong: Lessons from the past. Multi-stakeholder workshop: Review of forest rehabilitation initiatives in Guangdong: Lessons from the past. Guangzhou. http://www.cifor.cgiar.org/rehab/ _ref/countries/China/report/2.htm. 